\title{
An unusual case of action-induced jerking
}

Jan A.F. Coebergh, MBBS, FRCP

Neurology ${ }^{\circledR}$ 2018;91:361-362. doi:10.1212/WNL.0000000000006043

Figure 1 Lesion visible on MRI susceptibility-weighted imaging in left supplementary motor area

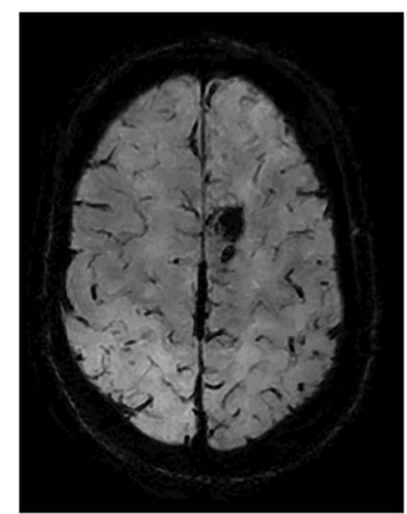

A right-handed 62-year-old man developed a persistent involuntary jerky movement of the right arm when initiating movements like getting up from a chair or opening the door, persisting while the task is performed (video 1). CT head scan was normal. Elsewhere, a functional movement disorder was diagnosed. An MRI head revealed an old hemorrhage in the left supplementary motor area (SMA) (figures 1 and 2), an area involved in movement initiation and sequencing complex movements. EEG and Bereitschaftspotential were normal. A year later, he developed generalized nocturnal seizures. Misdiagnosis of an SMA stroke as a functional movement disorder has previously been reported. ${ }^{1}$

\section{Study funding}

No targeted funding reported.

Figure 2 Lesion visible on MRI susceptibility-weighted imaging in left supplementary motor area
Correspondence

Dr. Coebergh

jan.coebergh@nhs.net

MORE ONLINE

- Video

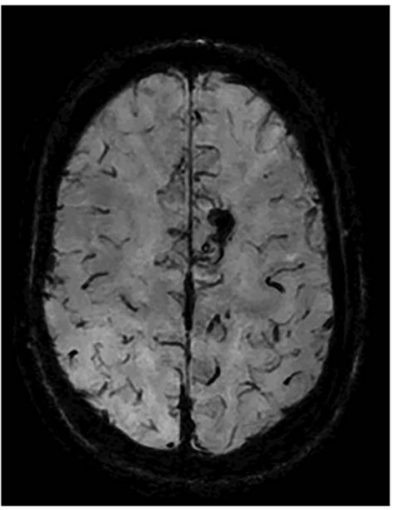

From the Department of Neurology, Ashford/St. Peter's Hospital, Chertsey; and Department of Neurology, St. George's Hospital, London, UK.

Go to Neurology.org/N for full disclosures. Funding information and disclosures deemed relevant by the author, if any, are provided at the end of the article. 


\section{Disclosure}

The author reports no disclosures relevant to the manuscript. Go to Neurology.org/N for full disclosures.

\section{Reference}

1. Mathew P, Batchala P, Muttikkal T. Supplementary motor area stroke mimicking functional disorder. Stroke 2018;49:e28-e30.

\section{Are You Ready to Maximize Your Medicare Reimbursement?}

Use the AAN tools and resources to earn positive payments and avoid penalties under MIPS.

Take action today, visit AAN.com/view/QPP

\section{Get 10 AAN Practice Management Webinars for Less than \$19 Each}

The AAN is dedicated to helping neurologists improve their practices and delivery of quality care to their patients. The AAN's Practice Management Webinars provide the valuable insights and tools you need to navigate through the ever-changing health care landscape-and receive year-end CME credits!

Purchase webinars individually for $\$ 99$ each, or subscribe to the complete series of 2018 webinars for only $\$ 189$-that's less than $\$ 19$ per webinar! See the list of webinars and subscribe at AAN.com/view/pmw18.

\section{Sign Up for the AAN's Axon Registry}

The AAN encourages its US members to show their interest in participating in the Axon Registry ${ }^{\circledR}$ by signing up today.

Use the Axon Registry to:

- Simplify reporting requirements under MACRA's Quality Payment Program and avoid penalties while reducing your administrative burden

- Meet your MOC Part IV requirements and waive up to eight credits of Part II Self-Assessment

- Choose from 22 AAN neurology-specific quality measures that fit your practice

- Use data to understand your practice and identify where improvements can be made to patient care

- Manage your patients at a population level; look at a specific group of patients based on conditions, risk factors, demographics or outcome

- Demonstrate your value to payers when negotiating reimbursement

- Enjoy multi-year, fee-free access when you sign the agreements and integrate your EHR with the registry

Learn more at AAN.com/view/Axon and send your questions to registry@aan.com. 


\title{
Neurology
}

\author{
An unusual case of action-induced jerking \\ Jan A.F. Coebergh \\ Neurology 2018;91;361-362 \\ DOI 10.1212/WNL.0000000000006043
}

This information is current as of August 20, 2018

\section{Updated Information \& Services}

References

Subspecialty Collections

Permissions \& Licensing

Reprints including high resolution figures, can be found at: http://n.neurology.org/content/91/8/361.full

This article cites 1 articles, 1 of which you can access for free at: http://n.neurology.org/content/91/8/361.full\#ref-list-1

This article, along with others on similar topics, appears in the following collection(s):

All Cerebrovascular disease/Stroke

http://n.neurology.org/cgi/collection/all_cerebrovascular_disease_strok

All Movement Disorders

http://n.neurology.org/cgi/collection/all_movement_disorders

Motor Control

http://n.neurology.org/cgi/collection/motor_control

Information about reproducing this article in parts (figures,tables) or in its entirety can be found online at:

http://www.neurology.org/about/about_the_journal\#permissions

Information about ordering reprints can be found online:

http://n.neurology.org/subscribers/advertise

Neurology ${ }^{\circledR}$ is the official journal of the American Academy of Neurology. Published continuously since 1951, it is now a weekly with 48 issues per year. Copyright (O) 2018 American Academy of Neurology. All rights reserved. Print ISSN: 0028-3878. Online ISSN: 1526-632X.

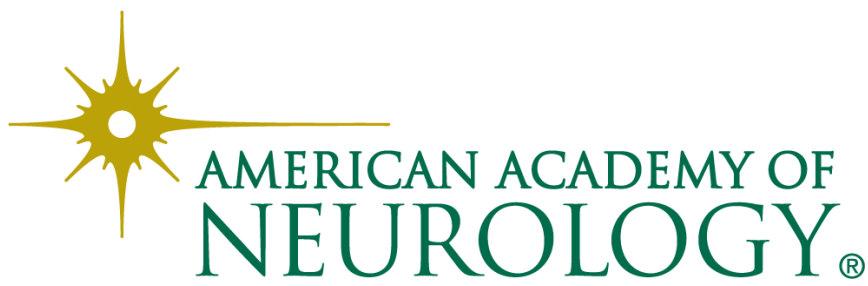

